\title{
Livros e vidas: atravessando fronteiras em Livro, de José Luís Peixoto, e Biografia involuntária dos amantes, de João Tordo
}

\section{Books and lives: crossing borders in Livro, by José Luís Peixoto, and} Biografia involuntária dos amantes, by João Tordo

Sílvia Amorim ${ }^{1}$

Sívia Amorim é professora titular na Universidade literatura portuguesa no (França) onde lecion Lusófonos.

E-mail: silvia.amorim@u-bordeaux-montaigne.fr.
RESUMO: Ao refletirmos sobre a noção de fronteira em obras de autores portugueses que representam a nova geração de escritores - Livro (2010), de José Luís Peixoto, e Biografia involuntária dos amantes (2014), de João Tordo -, pretendemos pôr em destaque algumas tendências recentes do romance. Verificamos que os limites do texto se expandem, revelando o novo lugar do romance na sociedade e na vida pessoal dos leitores. A hibridez (real/ficção) caracteriza o narrador em textos que renovam profundamente a escrita na primeira pessoa. A nosso ver, a perceção íntima - com caráter profundamente autêntico - do mundo, da sociedade e da história exposta no texto, revela o estatuto inédito do indivíduo na sociedade e representa uma tendência significativa do romance contemporâneo.

PALAVRAS-CHAVE: Narrativa na primeira pessoa; Fronteiras da ficção; Metalepse; Paradoxo; Indivíduo.

ABSTRACT: By reflecting on the concept of border in works by Portuguese authors who represent the new generation of writers - Livro (2010), by José Luís Peixoto, and Biografia involuntária dos amantes (2014), by João Tordo -, we wish to highlight some recent trends of the novel. We observe that the limits of the text are expanding, revealing the new position occupied by novels in our society and in readers' personal lives. The hybridism (reality/fiction) characterizes the narrator in texts that deeply renew the first-person narrative. In our view, an intimate perception - with authentic value - of the world, society and history exposed in the text, reveals the unprecedented status of the individual in society and represents a significant trend of the contemporary novel.

KEYwoRDS: First-person narrative; Borders of fiction; Metalepsis; Paradox; Individual. 
$\mathrm{P}$

roduzida num mundo cada vez mais globalizado, sujeito a profundas mutações socioeconómicas, ao avanço rápido das tecnológicas e a novos hábitos de consumo, a literatura atual reveste formas peculiares que, supostamente, refletem esse contexto específico. Géneros canónicos, como o romance, sofrem mudanças profundas nos seus conteúdos, estruturas e princípios, embora esses fenómenos sejam difíceis de abranger por ainda estarem a decorrer.

Entre as tendências mais relevantes da época atual, o advento da individualidade autónoma é, ao lado da economia de mercado e da eficiência tecnológica, o que melhor caracteriza os "tempos hipermodernos", assim designados por Gilles Lipovetsky. O filósofo analisa essa nova fase da modernidade como sendo uma situação inédita em que nenhum poder opositivo refreia o individualismo inerente à modernidade:

A sociedade que se vai constituindo é uma sociedade em que as forças de oposição à modernidade democrática, liberal e individualista já não são estruturadoras, em que os grandes alvos alternativos declinaram, em que a modernização já não encontra mais resistências organizacionais e ideológicas de fundo (LIPOVETSKY e CHARLES, 2004, p. 52, tradução nossa). ${ }^{1}$

Sébastien Charles, ao apresentar as principais linhas de pensamento de Gilles Lipovetsky, lembra que sendo absorvidas e recuperadas pela lógica da moda e do consumo, as normas tradicionais e antigas estruturas de sentido dão lugar à autonomia individual (LIPOVETSKY e CHARLES, 2004, p. 29-32). Porém, a ausência de mecanismos de controlo tem também conferido um caráter altamente paradoxal ao individualismo hipermoderno: embora mais informado, crítico e aberto, o indivíduo autónomo é também

\footnotetext{
${ }^{1} \mathrm{O}$ vácuo deixado pelo enfraquecimento das ideologias e normas tradicionais, assim como o advento da individualidade s̃̃o analisados de forma mais específicas no ensaio de Gilles LIPOVETSKY L'Ėre du vide. individualidade são analisados de forma mais esp
}

mais destruturado, crédulo e superficial, dividindo-se entre responsabilidade e leviandade, autodomínio e instabilidade (LIPOVETSKY e CHARLES, 2004, p. 22-29).

Esse "individualismo paradoxal"2 encontra certamente ecos na produção romanesca contemporânea, nomeadamente nas novas escritas da intimidade, podendo inclusive moldar o aspeto do romance e a própria maneira de o considerarmos. A questão do relacionamento da obra com o leitor e com o contexto sociocultural coloca-se aqui, levando-nos também a considerar o problema mais específico do delineamento das fronteiras entre o real e a ficção ${ }^{3}$. Nas últimas décadas, essas têm sido consideradas cada vez mais ténues, uma vez que se têm favorecido as noções de hibridez e interatividade em detrimento de uma dicotomia real/ficção (LAVOCAT, 2016, p. 11-12). No entanto, a definição da ficção e a exploração dos paradoxos acarretados pelo romance permanecem problemáticas atuais, reativadas na produção romanesca contemporânea.

No intuito de revelar algumas tendências do romance atual, selecionámos obras que, embora já conceituadas, pertencem à mais recente geração de autores e abrangem questões acima referidas, relacionadas com a escrita íntima, a representação do contexto sociocultural ou assuntos de cariz mais teórico, como a definição da fronteira entre o real e a ficção. Escolhemos dois autores que achamos representativos, ambos portugueses, nascidos

${ }_{2}^{2}$ Retomamos aqui o título do capítulo em que Sébastien Charles apresenta os grandes princípios das teorias de Gilles Lipovetsky sobre a época contemporânea (cf. LIPOVETSKY e CHARLES, 2004 p. 11-46).

3 Num estudo recente, Françoise Lavocat reafirma a existência de uma fronteira ontológica entre o real e a ficção (posta em causa, nomeadamente, pela perspetiva outrora em voga de uma ficção generalizada) mostrando que a transgressão repetida do limite entre esses dois mundos na prática literária atual longe de apagar as fronteiras, torna-as mais salientes. Para a autora, os artefactos culturais são "mundos longe de apagar as fronteiras, torna-as mais salientes. Para a autora, os artefactos culturais são "mundos possiveis imaginariamente fabricados" (LAVOCAT, 2016, p. 394) que apresentam um alto grau de hibridez. A autora defende a ideia de "encarar a ficção através das suas diferentes modalidades de hibridização com o factual, as quais realçam, na maioria dos casos, os contornos da ficcionalidade e da
factualidade em vez se os apagar" (LAVOCAT, 2016, p. 522, tradução nossa). 
em meados da década de setenta, cujas obras, embora bem diferenciadas, apresentam algumas semelhanças e complementaridades.

Incontornável no panorama literário contemporâneo, José Luís Peixoto publicou até hoje seis romances, todos traduzidos e distribuídos na escala mundial. Tendo iniciado a carreira em 2000, vencedor de prestigiados prémios, é emblemático da nova geração com uma obra que, embora já consagrada, continua em vias de composição. Livro (2010), quarto romance num percurso literário exemplar, evoca a emigração portuguesa para França, um fenómeno que atingiu o seu auge no final dos sessenta. A obra não deixa, no entanto, de revelar aspetos essenciais da realidade portuguesa atual e, ao mostrar o processo criativo que lhe subjaz, de instigar uma reflexão sobre literatura.

Assim como José Luís Peixoto, João Tordo foi galardoado pelo prémio José Saramago (em 2009) e tem uma obra já reconhecida, com nítida vocação internacional. Publicou nove romances, sendo Biografia involuntária dos amantes (2014) um dos mais recentes. Tal como Livro, o romance mostra o itinerário de um texto, interrogando a sua génese, interpretação e impacto, um texto intimamente ligado com quem o escreveu e com quem o lê, capaz de transformar uma vida, mas podendo também ser alterado pela própria leitura.

Ambos os romances revelam tendências da literatura atual, focando as suas características e preocupações essenciais, os desafios que se propõe de enfrentar, as relações que se tecem entre o texto, o autor, o leitor e o real. Cruzando as leituras e análises de Livro e Biografia involuntária dos amantes, verificaremos que ambos os textos apontam a complexidade do delineamento dos seus contornos: a sua origem e o seu porvir são questionados, assim como a sua inserção numa tradição e numa rede de outros textos, a sua inscrição numa determinada área geográfica... A questão das fronteiras entre a ficção literária e o real coloca-se também, levando-nos a refletir sobre as relações entre o "eu", o texto e o real no âmbito das novas formas de escrita íntima.

\section{Fronteiras do romance: origens, contornos e redes}

Livro e Biografia involuntária dos amantes colocam, assim como sugerem os respetivos títulos, um texto no centro do texto. A mise en abyme, embora um processo comum ao longo da história literária, apresenta aqui características invulgares: a prática autorreflexiva não contribui apenas para desvendar a natureza construída da narrativa ou os mecanismos que sustêm a ficção, mas interroga com agudez a origem, os limites e, de certa forma, a própria identidade do texto. 0 delineamento das fronteiras do romance também nos leva a explorar as relações entre a ficção e o real, as quais são sugeridas através de uma metáfora geográfica que assemelha a escrita a um lugar físico. Essa dimensão espacial também aparece através da cartografia literária que se vai esboçando, problematizando a inserção do romance na biblioteca universal, numa rede de outros textos ao lado dos quais passa a existir, partilhando com eles fronteiras incertas.

A alusão repetida ao lugar físico da fonte realça, em Livro, a importância da indagação da origem do romance. Efetivamente, o chafariz simboliza, além dos valores de fecundidade e maternidade a que geralmente está associado, a origem do texto, da inspiração ${ }^{4}$. A fonte remete para o cenário do abandono de Ilídio pela mãe, no incipit do romance, numa cena que decorre quando a criança tem apenas seis anos, em 1948. Nas mesmas páginas, encontram-se as primeiras alusões ao "livro" que a mãe entrega ao filho antes de o deixar, o

${ }^{4}$ A fonte e o nascente estão sempre associados com a origem, assim como confirma o verbete do Dictionnaire des Symboles: "Sabe-se que, nas culturas tradicionais, o nascente simboliza a origem da vida, e, de forma mais geral, qualquer origem, do génio, do poder, da graça, da felicidade" (CHEVALIER 1982, p. 903-904, tradução nossa). 
objeto aparecendo assim fisicamente, tanto para as personagens como para o leitor, embora com um conteúdo ainda ignoto. Mais adiante, a fonte é o lugar em que se dá, numa noite de agosto de 1973, o encontro de Adelaide com Ilídio e a geração do filho, chamado Livro: "Quando a Adelaide saiu detrás do chafariz, já uma vírgula iniciara o percurso em direção ao seu útero." (PEIXOTO, 2010, p. 101). O autor joga com a semelhança morfológica entre o sinal tipográfico da vírgula e o espermatozoide, ligando inseparavelmente a geração do narrador-personagem com o ato da escrita. A partir do nascimento de Livro, o romance toma um novo rumo deixando de ser uma narrativa na terceira pessoa para se tornar autodiegético, aparecendo assim a primeira ocorrência do pronome "eu": "Foi às duas e meia da tarde que eu nasci" PEIXOTO, 2010, p. 204). Assim sendo, a primeira parte do romance (204 páginas ao todo) antecede o nascimento do narrador, preparando, de certa forma, o seu aparecimento: de forma paradoxal, ele não se apresenta como uma fonte, mas sim como uma figura gerada pelo texto, que aparece posteriormente.

Em Biografia involuntária dos amantes, a questão da origem do texto também se nos afigura essencial, sendo a génese do manuscrito de Teresa, em torno do qual gira o romance, constantemente interrogada pelo narrador autodiegético, leitor do manuscrito. A morte da suposta autora veda o acesso à fonte primitiva, erguendo também algumas suspeitas quanto à autoria e levando o narrador a investigar sobre o dito "manuscrito de Bríon". A indagação consiste em telefonemas, viagens, conversas, encontros, trocas de e-mails... que expandem o manuscrito, distendendo as suas fronteiras. A natureza referencial ou ficcional do documento é problemática, não se sabendo se terá sido escrito por Teresa, partindo de uma experiência pessoal, ou inventado por Benxamín, um bibliotecário galego amigo da falecida.

O destinatário do manuscrito é Miguel Saldaña Paris, ex-marido de Teresa, incapaz de ler o texto por estar ainda demasiado afetado pela sua relação com a ex-mulher e por recear que o conteúdo do manuscrito o derrube definitivamente. Por conseguinte, Saldaña Paris pede a um amigo para ler o documento e para lho relatar, atenuando assim o seu impacto, o que revela a importância decisiva que pode revestir um texto na vida de um indivíduo. 0 narrador-personagem deixa-se rapidamente seduzir pelo manuscrito que, para ele - que quase nada conhece sobre os protagonistas - tem um aspeto ficcional:

Esse enigma deixava-me muito curioso, porque o encanto e a desilusão de algumas daquelas páginas tinham o sabor de um romance e interessavame saber o que sucedia àquelas personagens. Ficava por contar quase tudo: os eventos que conduziriam, mais tarde, ao encontro de Teresa com o meu amigo, o que os levara à separação e os anos subsequentes (TORDO, 2014, p. 191).

O papel do leitor do manuscrito é fundamental: ele interpreta o texto, determina a sua autoria, define a seu estatuto ficcional ou referencial e, por fim, acaba por alterar o seu conteúdo para preservar o amigo. Sendo assim, ele molda o texto, desempenhando também, de certa forma, um papel determinante na sua génese. 0 narrador-personagem, ao investigar sobre a vida dos protagonistas do manuscrito de Bríon, que para ele se apresentam como seres ficcionais, realiza o sonho de qualquer leitor: transgredir a fronteira entre a ficção e o real, recorrendo à metalepse ${ }^{5}$. A relação entre o romance e o manuscrito em abismo permite focar, de forma subtil, o fenómeno da "transficcionalidade", isto é, a possibilidade de expandir uma ficção literária usando elementos do universo ficcional ${ }^{6}$, movendo assim as

5 Jean-Marie Schaeffer (2005, p. 10-11) lembra que a metalepse, fenómeno inicialmente definido por Gérard Genette, consiste na contaminação do nível da narrativa por elementos oriundos do nível dos eventos narrados.

6 Distinguindo-a da intertextualidade, Richard Saint-Gelais afirma, a propósito da "transficcionalidade" (um termo de sua autoria), que ela supõe "o relacionamento de dois ou vários textos na base de uma comunidade ficcional" (SAINT-GELAIS, 2001, p. 45 nossa tradução). 
suas fronteiras. Esse processo baseia-se no caráter incompleto dos mundos possíveis da ficção e no princípio de fechamento do texto, que não diz mais do que aquilo que nele está escrito. Ao usar elementos da ficção, o autor prolonga esse universo aparentemente fechado e pode, inclusive, corrigi-lo. Além disso, se a ficção literária não diz tudo sobre o universo das personagens ${ }^{7}$, o leitor, esse sim, desempenha um papel essencial no acabamento do texto que está a ler, realizando o que o investigador canadense Richard Saint-Gelais chama de "fervilhante e silencioso trabalho de complementação exercido pelos leitores de ficções" (SAINT-GELAIS, 2001, p. 62, nossa tradução). De forma indireta, João Tordo toca nesses assuntos ${ }^{8}$ sendo o romance, a "biografia", um desenvolvimento do manuscrito de Bríon: o trabalho de finalização do texto pelo leitor está em destaque, assim com a possibilidade de expandir um universo ficcional e de remover as suas fronteiras, pelo impulso de uma vontade individual.

O manuscrito de Bríon constitui um caso clássico de mise en abyme que podemos, seguindo a tipologia estabelecida por Lucien Dällenbach, qualificar de réduplication simple (o que corresponde à mise en abyme de tipo I) ${ }^{9}$. Os dois textos não se confundem embora apresentem um certo grau de semelhança por terem ambos um caráter biográfico, por estarem escritos na primeira pessoa e por apresentarem assuntos e protagonistas comuns. É precisamente a distância entre os dois textos que revela o papel fulcral do narrador-personagem: o romance, embora fragmentado e composto por elementos heterogéneos, apresenta-se-nos coeso, completo e provido de sentido, ao passo que o manuscrito em abismo permanece

7 Richard Saint-Gelais lembra, por exemplo, que não nos é possível conhecer o nome da avó de Emma Bovary, uma vez que ele nunca é referido no romance de Flaubert.

É de assinalar que João Tordo pratica a "transficcionalidade". No seu último romance, O Paraíso segundo Lars D. (2015), por exemplo, o herói é o autor de um livro intitulado O Luto de Elias Gro, também uma obra de João Tordo..

9 Para a apresentação desta tipologia, remetemos a DÄLLENBACH (1977, p. 139-148). desconexo, inconcluso e algo ininteligível. A partir de elementos dispersos, de informações confirmadas ou falsas, de fontes múltiplas, o narrador acaba por produzir uma "biografia involuntária”. Não sendo biógrafo nem escritor, ele consegue, contudo, esboçar o retrato de uma vida alheia ao procurar coesão e sentido no meio de informações dispersas. Destaca-se assim o papel essencial do leitor na génese do texto, deixando entender também que qualquer indivíduo se pode tornar autor, ligando elementos desconexos para escrever o seu próprio romance (uma possibilidade, uma configuração pessoal, entre tantas), invertendo-se assim os papéis de leitor e autor.

Em Livro, a mise en abyme atinge um grau invulgar, abrangendo todos os tipos de integração da obra na obra propostos por Lucien Dällenbach e confundindo-os. Um livro é oferecido a Ilídio pela mãe quando esta o abandona ao emigrar para França. 0 mesmo livro é presenteado por Ilídio a Adelaide, marcando o namoro dos dois jovens, e é levado pela moça na sua viagem para França. Definitivamente ligado com a temática da emigração, o livro segue as andanças de Adelaide, na sua mala, acompanhando-a até ao local de trabalho, uma biblioteca pública onde é empregada de limpeza. Escrito em português, o livro é identificado por Constantino, também ele emigrante, futuro namorado e marido de Adelaide: enquanto veículo de uma cultura e de uma língua, o livro torna-se assim o símbolo dos laços que ligam os membros de uma comunidade. O livro serve então de suporte para a comunicação das duas personagens que iniciam um diálogo colocando círculos e escrevendo assim, no próprio texto tornado palimpsesto, a história do seu encontro. Estranhamente, as personagens não leem o livro, o conteúdo permanece vedado e misterioso, pelo menos na primeira parte do romance. Seguindo a terminologia de Lucien Dällenbach, podemos considerar que este livro no livro constitui uma narrativa em abismo de tipo I.

Ao longo do romance, vão aparecendo outros tipos de mise en abyme. Com efeito, Livro, o narrador-personagem, conta que num Natal passado em 
Portugal a mãe lhe oferece um livro intitulado Livro: "um Livro para o Livro" (PEIXOTO, 2010, p. 223). Cosme, um amigo, manda-lhe outro exemplar três dias depois, o que sugere que o próprio leitor pode também possuir o mesmo livro, o que verifica ao descobrir que Livro é uma obra de José Luís Peixoto, amigo de infância da personagem. Assim sendo, trata-se de uma mise en abyme de tipo II, chamada por Lucien Dällenbach de réduplication à l'infini: estamos a ler um romance dentro do qual uma personagem está a ler o mesmo romance do que nós, onde se trata de uma personagem que está a ler o mesmo romance...

Porém, José Luís Peixoto vai mais longe, revelando que o que estamos a ler é o próprio livro em abismo ${ }^{10}$ : a certa altura, o leitor depara-se com páginas em que aparecem círculos e, no cabeçalho, a assinatura de Constantino (PEIXOTO, 2010, p. 228), percebendo que esses elementos foram introduzidos por Adelaide e Constantino aquando do seu encontro na biblioteca. O leitor descobre então que o livro de Ilídio, o do início, é o mesmo que ele próprio está a ler, coincidindo também com o Livro de José Luís Peixoto:

Seguras o meu nome. Este livro que estás a ler e que estou a escrever, onde estamos, é exactamente o mesmo que a minha mãe me pousou nas mãos, como na primeira frase. Também esse livro era este. 0 início também é agora (PEIXOTO, 2010, p. 262-263).

O leitor tem nas mãos um livro que transgride as fronteiras da ficção, passando do universo da ficção para o real, entregue pelo autor, no mesmo gesto que leva a mãe a dá-lo ao filho. Esse gesto simboliza também a transmissão a José Luís Peixoto, pelos próprios pais, de uma herança constituída pela sua experiência da emigração em França.

${ }^{10}$ Trata-se, neste caso, de uma mise en abyme de tipo III, que Lucien Dällenbach chama réduplication aporistique, ou ainda dédoublement paradoxal (DÄLLENBACH, 1977, p. 142).
O complexo jogo de espelhos revela que o livro referido logo nas primeiras páginas do romance preexiste ao ato de narração e de escrita que o gera, uma vez que o paradoxo de um livro já escrito e ainda por escrever é possível no romance. O livro só passa verdadeiramente a existir quando lido, um processo completado apenas nas últimas linhas e palavras do texto: outro grande paradoxo do romance reside no facto de a leitura, ao esgotar o texto, também o completa, consumando-o e dando-lhe vida ao mesmo tempo.

A questão das fronteiras do romance, focada através do processo autorreflexivo da mise en abyme e da consideração da génese do texto, também é encarada na sua dimensão espacial e geográfica. A viagem e o deslocamento são aspetos recorrentes em ambas as obras, os livros ultrapassando as fronteiras políticas, culturais e linguísticas ao apresentarem uma dimensão internacional. 0 emblema dessa internacionalização da literatura é o livro, em português, de José Luís Peixoto, levado clandestinamente para França na mala de Adelaide, que acaba por encontrar um lugar numa biblioteca francesa, integrando o património literário comum. Além disso, ao levar para Portugal a biblioteca de Constantino, Adelaide e Livro introduzem num país muito tempo enclausurado e controlado pela censura, um painel de obras outrora inacessíveis, superando as fronteiras que até ali isolavam as literaturas nacionais.

É de assinalar, por outro lado, que as narrativas de João Tordo decorrem sempre em cenários que pouco ou nada têm a ver com Portugal ${ }^{11}$, com personagens que não são necessariamente de origem portuguesa e que, muitas vezes, não falam português. O romance Biografia involuntária dos amantes é moldado pelas andanças das personagens que percorrem itinerários complexos, indo e vindo entre Espanha (Galiza, Catalunha...),

${ }^{11}$ A ação de Hotel Memória (2007) decorre em Nova-York, O Bom Inverno (2010) na Hungria e na Itália, O Luto de Elias Gro (2015) numa ilha anglo-normanda etc. 
Portugal, França, Inglaterra, Leste europeu, México, Canadá, passando também por uma série de "não-lugares" próprios da época contemporânea ${ }^{12}$. Com efeito, o casal Teresa/Saldaña Paris conhece-se num comboio que segue para Barcelona. Além disso, a primeira cena do romance relata uma viagem de carro numa autoestrada galega e o embate com um javali, na noite em que o narrador e Saldaña Paris, de regresso da ilha de Arousa, falam pela primeira vez do manuscrito de Teresa.

Quanto a Livro, o romance apresenta de forma arquetípica a vaga de emigração que levou milhares de portugueses a partirem para França no século XX. Um pequeno desenho que representa uma mala aparece na primeira página de cada capítulo como emblema dessa emigração, muitas vezes clandestina e atribulada, que, apesar de prefigurar as migrações atuais, também apresenta características remotas sendo as fronteiras entre países geográfica e culturalmente próximos, apresentadas como difíceis de superar. O romance constitui também um apanhado de todas as problemáticas ligadas com a emigração: motivações da partida, saudades da terra natal, necessidade de se adaptar a uma nova cultura, problemas socioeconómicos (vida nos bairros de lata de Champigny ou Saint-Denis, na região parisiense; sujeição a empregos subalternos...), dificuldades ligadas com o regresso a Portugal, perda do contacto linguístico e cultural da segunda geração, confraternização entre imigrantes... Também neste romance o deslocamento e a viagem ligam-se de forma indestrinçável com a escrita, assim como sugere o seguinte trecho: "Assim que chegou à França, escreveu uma carta ao Ilídio, Meu amor, não imaginas o quanto te quero bem, mas não recebeu resposta [...]. Mais tarde, teve de conter-se para não lhe escrever mil cartas." (PEIXOTO, 2010, p. 143).

${ }^{12}$ No sentido antropológico que Marc Augé confere a essa noção definida como "um espaço que não se
pode definir nem como identitário, nem como relacional, nem como histórico" (AUGÉ, 1992, p. 100 tradução nossa).
A analogia aqui aludida entre a obra literária e o espaço físico corresponde à conhecida "correlação entre a espacialidade e a literatura" referida por Christine Montalbetti (1997, p. 110 ${ }^{13}$ que permite considerar toda a escrita/leitura como percurso e o mundo como um livro a ser decifrado. Porém, nos romances contemporâneos, essa analogia revela novas formas de relacionamento do indivíduo com o espaço, tendo desenvolvido outras maneiras de o ocupar e de se deslocar nele. Isso também faz eco a uma nova maneira de se relacionar com o texto e com a literatura, com um maior grau de abertura para as literaturas estrangeiras e para um romance contemporâneo que integra a dimensão internacional, sendo moldado pelos deslocamentos, comunicações e viagens.

Tanto Livro como Biografia involuntária dos amantes apresentam universos de livros que nos levam a refletir sobre o lugar de ambos os romances numa rede de textos, definindo também assim as suas fronteiras. A biblioteca é um lugar de destaque: em Livro, é o sítio em que Adelaide trabalha e onde conhece Constantino, bibliófilo, possuidor de uma biblioteca pessoal fora do comum. Essa biblioteca é transferida de um apartamento parisiense para o outro e, finalmente, para Portugal, para a casa comprada por Adelaide. O livro e a biblioteca, associados com a emigração e com meios sociais pouco favorecidos e cultos, lidam assim com contextos com que habitualmente não coabitam (segundo os preconceitos mais comuns).

Livro arruma os livros nas estantes, tentando encontrar um critério para organizá-los, uma norma tão incongruente como a ordem alfabética ou o aspeto físico dos autores, mas em todo o caso totalmente pessoal. Ao

${ }^{13} \mathrm{O}$ recurso a metáforas espaciais para evocar o texto tem-se tornado quase um lugar-comum, assim como assinla Christine Montalbetti. 0 texto e a história são encarados em termos de território, sendo notória a "riqueza da declinaç̃̃o do paradigma da viagem para designar as operaç̃̃es da escrita e da notória a "riqueza da declinação do paradigma da viagem para designar as operações da escrita e da leitura" (MONTALBETTI, 1997, p. 108 tradução nossa). A própria crítica usa metáforas geográficas par falar no texto (p. 106-108) e e de assinalar, por seu lado, "a natureza livresca do mundo" (p. 120) que
faz com que se proceda a uma "leitura" do real. 
proceder a essa ordenação, a personagem vai questionando a possibilidade de classificar a literatura, mostrando que nenhum critério é realmente pertinente e que qualquer tentativa para categorizar um livro não passa de mera convenção. Da mesma forma, o que nos leva a constituir a nossa biblioteca pessoal, apresenta-se como sendo algo fortuito. Para Livro, por exemplo, a estranheza dos nomes dos autores constitui um critério de escolha:

Qualquer combinação de vogais e consoantes é própria para construir um nome de escritor. No passado, alcançando resultados diversos, interesseime pelas mais variadas obras a partir da estranheza que me causou o nome dos seus autores: Hella Wuolijoki, Ryenchinii Choinom, Islwyn Ffowe Elis [...] (PEIXOTO, 2010, p. 222).

Na segunda parte do romance, as personagens estão claramente envolvidas num mundo de livros, sendo referidos autores tão variados como Homero, Michel Houellebecq, Emily Dickinson, Jules Vernes, Émile Zola, Charles Baudelaire, por um narrador que lê À la recherche du temps perdu para passar o tempo durante as longas tardes de verão em Portugal, e que mata mosquitos com um livro de poemas de Ezra Pound (cuja simpatia pelo regime fascista de Mussolini é notória...).

Vai-se construindo um mundo de papel e o próprio Livro, assim como afirma Miguel Real na sua crítica ao romance (2011, p. 10), constitui uma "síntese da história do romance português desde Eça e Camilo", com referências óbvias aos grandes movimentos literários dos dois últimos séculos (realismo, naturalismo, modernismo, neorrealismo, existencialismo, pós-modernismo...). Podemos frisar também que o romance se refere a vários géneros, alguns considerados menores, como a ficção científica (na cena da mulher-lobo, durante a travessia da fronteira espanhola), o romance negro (quando Livro mata uma mulher), os jogos literários outrora na moda (como o OuLiPo)... Além disso, José Luís Peixoto encena um leque alargado de relações "transtextuais" 14 : além da já referida intertextualidade, ele estabelece um jogo com o paratexto referindo-se ao título da obra ou introduzindo notas de rodapé. A "metatextualidade" também aparece num comentário em que o narrador reproduz, segundo uma lógica hipertextual, o estilo da crítica literária mais cáustica:

O enredo é frouxo, invertebrado e, nos momentos esparsos em que consegue encaixar-se com interesse relativo, narra experiências banais, histórias que não se distanciam daquelas que poderiam pertencer ao vizinho ou, quando muito, ao vizinho do vizinho. Um episódio de licantropia e o desfecho sanguinário de uma personagem mal desenvolvida apenas acrescentam ausência prosaica de lógica [...] (PEIXOTO, 2010, p. 224).

Livro assume assim todos os papéis, sendo autor, narrador, personagem, leitor, crítico, editor, teorizador, objeto... Em Biografia involuntária, a mesma ideia é sugerida já que o narrador acaba por assumir, além de personagem, o papel de autor, leitor e comentador. Porém, ao referirem diferentes movimentos, teorias literárias e técnicas da ficção romanesca, os dois autores não se situam, a nosso ver, numa perspetiva de paródia pós-moderna. José Luís Peixoto e João Tordo mostram que integram uma tradição literária e conhecimentos teóricos, que estes fazem parte de si e das suas obras, e que eles os usam com toda a liberdade, sem necessariamente se inserirem numa escola ou num movimento, ultrapassando essas noções que se tornam pouco pertinentes no contexto atual.

Como Livro, Biografia involuntária dos amantes afigura-se-nos como um mundo de papel e tinta, em que tudo (personagens, espaço, assunto...) está vinculado com a escrita. Com efeito, o narrador é um professor universitário que está na fase de redação de uma tese de pós-doutoramento

${ }^{14}$ Referimo-nos à "transtextualidade" enquanto relação de um texto com outro texto (GENETTE, 1982, p. 7). 
que ele consegue melhorar e concluir graças à experiência vivida com o amigo Saldaña Paris. Este é um poeta mexicano que, depois de uma fase de depressão, deixa a poesia lírica para se tornar romancista. Além das viagens e experiências, a evolução da sua carreira está estreitamente ligada com os outros escritores que o inspiram ou, por vezes, dissuadem de escrever (por exemplo, os autores sul-americanos Adolfo Bioy Casares, Jorge Luís Borges ou Roberto Bolaño), lembrando assim que o encontro com a obra de um escritor pode ser tão decisivo como o encontro com o próprio indivíduo. Aliás, o romance Biografia involuntária dos amantes apresentase como o resultado do encontro com a obra do poeta mexicano Daniel Saldaña Paris, o que parece indicar a sua forte componente intertextual e o agradecimento, no paratexto, dirigido ao escritor. O romance inscrevese, por conseguinte, num percurso pessoal feito de encontros, e insere-se numa rede de afinidades e parentescos com outros textos. É de destacar que, no romance, as personagens se ligam por intermédio da escrita e dos textos: o amigo de infância de Teresa, Jaime, é escritor e é graças a ele que Teresa conhece Benxamín, o amigo bibliotecário; por seu lado, Antonia Mac Kay relaciona-se com Saldaña Paris por trabalhar no setor da edição... Como em Livro, este universo literário convive com a realidade mais prosaica e com as esferas mais afastadas da vida intelectual, o romance mergulhando o leitor no mundo do banditismo, do tráfico, do incesto, da violência, do crime... Teresa, autora do manuscrito que desempenha um papel central no romance, é aliás uma mulher pouco dada à leitura que mal sabe falar espanhol, misturando o português, o galego e o castelhano. Esta aproximação entre o livro e a realidade social mais trivial parece indicar que a literatura, por meio das novas tecnologias, recentes mutações socioeconómicas e novos hábitos de leitura, envolve todas as esferas da sociedade, não se detendo nas bibliotecas e nos meios mais intelectualizados.

\section{Novas escritas do "eu": os livros que somos}

Ao indagarmos a noção de fronteira não podemos deixar de nos debruçar sobre a questão do género que também permite, em princípio, definir e circunscrever a obra literária. 0 estatuto problemático do "eu" em ambos os romances acaba por trazer uma certa indefinição genérica. Trata-se de narrativas na primeira pessoa que vão oscilando entre a biografia, a autobiografia, a autoficção... constituindo novas expressões da intimidade e revelando maneiras inéditas para o "eu" de lidar com o mundo, a sociedade e a História. No fim de contas, é a própria natureza ontológica do "eu" que acaba por ser interrogada no âmbito da sua relação com a ficção e com o texto.

Tanto Livro como Biografia involuntária dos amantes renovam de forma original a escrita na primeira pessoa ${ }^{15}$. Embora se apresentem de antemão como biografias (é, pelo menos, o que os títulos parecem indicar ${ }^{16}$ ) e tratem de assuntos como os dramas alheios ou a história da emigração, ambas as obras possuem um teor íntimo.

Livro é um romance em que o "eu" é altamente singular e paradoxal: o narrador-personagem, Livro, autor do romance intitulado Livro, brincava em criança com José Luís Peixoto ${ }^{17}$. Porém Livro e José Luís Peixoto confundem-se de forma paradoxal, sendo autores do mesmo romance, Livro: "Estou

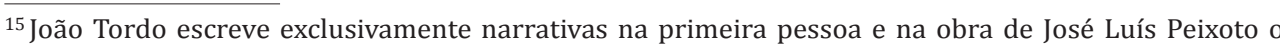
estatuto do "eu" é problemático. Veja-se, por exemplo, Morreste-me (2000), um texto profundamente autobiográfico que o paratexto apresenta, no entanto, como sendo uma ficção. Em Cemitério de Pianos (2006) aparecem vários narradores totalmente paradoxais, um deles estando morto e o outro correspondendo simultaneamente a duas personagens distintas, um avô e o seu neto. É de assinalar também os trabalhos académicos que têm surgido sobre o assunto, como, por exemplo, a tese de doutoramento de Vânia Almeida Rego, La mise en scène du "je" dans l'oeuvre de José Luís Peixoto: problématiques de l'écriture de soi (2015).

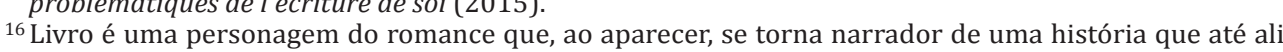
era contada na terceira pessoa. Essa história, o relato dos acontecimentos que levaram ao encontro dos seus pais e à sua conceção, é a sua vida. Paradoxalmente, a biografia é também uma autobiografia.

${ }_{17} \mathrm{O}$ autor aparece então no romance, passando a fazer parte dele, infringindo a fronteira entre o real e a ficção graças a uma metalepse. 
aqui, sentado a esta mesa, com este teclado de computador à frente [...]" (PEIXOTO, 2010, p. 260). Mas esse narrador chamado Livro é também o próprio livro, enquanto objeto personificado, que se vai dirigindo ao leitor: "[...] agradeço-te pela claridade que entra por esta janela e por tudo aquilo que me constitui, agradeço-te por me teres deixado existir, agradeço-te por me teres trazido até à última página e por seguires comigo até à última palavra." (PEIXOTO, 2010, p. 263). Por conseguinte, o narrador, a personagem, o autor e o próprio livro confundem-se, de forma totalmente indestrinçável, numa mesma (id)entidade ${ }^{18}$ profundamente híbrida.

Livro é também uma projeção do "eu" do autor: sendo filho de pais imigrantes, oriundo de um país, de um meio social e de uma época marcados pela emigração, ele próprio é um produto desse fenómeno que integrou e que faz parte da sua história pessoal. Além disso, José Luís Peixoto também passa a pertencer a essa história por escrever sobre o assunto, por recolher, na ficção, testemunhos de pessoas que ele conhece pessoalmente. 0 romance pode ser considerado uma autoficção sendo o "eu" uma projeção do autor que se reinventa a si-próprio. Adotando essa definição ampla e a tipologia propostas por Vincent Colonna, podemos classificar Livro na categoria da "autoficção fantástica", definida da seguinte maneira:

O escritor está no centro do texto, como numa autobiografia (é o herói), embora transfigure a sua existência e a sua identidade numa história irreal, indiferente à verosimilhança. 0 duplo projetado torna-se uma personagem fora do vulgar, um autêntico herói de ficção que seria impossível assemelhar à imagem do autor. Ao invés da postura autobiográfica, não se limita a acomodar a existência, mas sim, inventa-a: a distância entre a vida e a escrita é irredutível, a confusão impossível, a ficção de si é completa (COLONNA, p. 75, 2004, tradução nossa).

${ }^{18}$ José Luís Peixoto afirma essa identidade numa entrevista intitulada "O Livro sou eu. Sou eu mascarado" (2010). O autor explica que, embora não tenha vivido pessoalmente a história da emigração - tendo nascido ano e meio depois de os pais terem regressado de França -, foi, no entanto, recolhendo informações e testemunhos de pessoas que tiveram essa experiência.
A história da emigração, passada no crivo do romance, torna-se uma realidade íntima, profundamente relacionada com sentimentos pujantes de abandono e saudade, distanciando-se de alguns estereótipos habitualmente associados com a emigração portuguesa. Alcançamos o fenómeno da emigração através da história singular de personagens que deixam a aldeia alentejana, enclausurada e atrasada, por motivos que pouco têm a ver com a situação político-económica do país, orientando-nos de antemão para a esfera privada e íntima. Com efeito, Adelaide é levada a emigrar pela tia, a Dona Lubélia, que a quer afastar de Ilídio por receio do escândalo, ou por mero ciúme. Por sua vez, Ilídio deixa a terra natal para seguir a namorada, embora não a consiga encontrar, e ambos acabam por ficar em França, estabelecendo ligações com outros emigrantes e participando na história da emigração.

A intimidade escreve-se de forma renovada por um "eu" transfigurado pela ficção, constituído por um mosaico de elementos reais e ficcionais ${ }^{19}$, o que permite um ponto de vista genuíno, autêntico, ainda que altamente subjetivo, sobre a sociedade e a história. Essa hibridez leva o leitor a adotar uma leitura também ela híbrida, assim como indica Marie-Laure Ryan:

A leitura do texto híbrido - ou a leitura híbrida de um texto - não consiste num fraco grau de adesão, mas sim, numa alternância entre uma atitude de imersão, provocando no leitor o prazer da contemplação do mundo textual, e uma atitude de avaliação, que permite comparar esse mundo com a própria representação do mundo real, e enriquecer essa representação ao extrair a informação do texto. Quase podemos considerar que o leitor adota ambas essas atitudes numa sucessão tão rápida que acabam confundindo-se (RYAN, 2001, p. 34, tradução nossa). ${ }^{20}$

${ }^{19}$ Marie-Laure Ryan explica que podemos optar por duas maneiras de considerar a hibridez da ficção, segundo um modelo contínuo ou digital (a autora opta pelo compromisso entre as duas abordagens): "No modelo contínuo, os textos híbridos são cinzentos - uma mistura homogénea mais ou menos escura; no modelo digital a hibridez é um mo cinzentos - uma mistura homogenea mais ou menos escura; no modelo digital, a hibridez é um mosaico de elementos pretos e brancos, com uma cor que ${ }^{20}$ determina a classificação global do texto" (RYAN, Marie-Laure, 2001, p. 25, nossa tradução)

ara descrever a atitude do espectador/leitor perante uma ficção, Jean-Marie Schaeffer fala de um cindido" que combina a imersão e a consciência da representação (SCHAEFFER, 1999, p. 190). 
Em Biografia involuntária dos amantes, o nome do narrador-personagem não é nunca referido, o que traduz uma incerteza identitária que acaba por criar uma certa ambiguidade, embora os escassos dados sobre a identidade desse narrador (universitário, galego, divorciado, pai de uma filha...) não coincidam com a biografia de João Tordo. Esse narrador, que permanece anónimo, vai juntando dados e informações que acabam por constituir uma história sem que o projeto seja fazer uma biografia. Essa composição é impulsionada pela vontade de entender a tristeza profunda de Saldaña Paris e os mistérios da sua relação com a ex-mulher. Porém, a biografia apresenta um alto teor subjetivo já que o narrador vai interpretando e alterando os documentos que recolhe, acabando inclusive por falsificar o manuscrito de Bríon para evitar magoar o amigo:

"Ela fala de mim? Em alguma parte do manuscrito?"

"Já te disse: não acredito que tenha sido ela a escrevê-lo." Ele ignorou o meu comentário e insistiu.

"Sim, fala de ti", retorqui, sem saber bem se mentia ou se dizia a verdade (TORDO, 2014, p. 219).

Em vez de te contar as coisas que queria contar-te, conto-te outras; aquelas que nunca aconteceram mas que seriam as justas e as certas, as coisas que nunca encontrei desde que adormeceste de olhos abertos. Conto-te que a Teresa nunca teve um amante, porque o Franquelim nunca existiu [...]. Conto-te que o manuscrito de Bríon, as páginas que nos incendiaram, é uma delicada fabricação de uma mulher muito doente e de um bibliotecário insurrecto, carregado das fantasias e das panaceias que sempre usamos para tratar as dores dos outros (TORDO, 2014, p. 403-404).

A amizade que o liga a Saldaña Paris faz com que o narrador, implicado pessoalmente, altere a vida do seu amigo. Ao mentir a respeito do conteúdo do manuscrito - afirmando que Teresa não teve qualquer amante durante a época do casamento -, ele salva-o da depressão e do suicídio, intervindo na sua história.

Persiste, todavia, uma incerteza quanto à identidade dos "amantes" referidos no título da obra. O leitor associa-os de antemão com Teresa de Sousa e Miguel Saldaña Paris, mas não nos parece óbvio que se trate necessariamente da biografia desse casal. Ao mergulhar na história do amigo, o narrador vai, de facto, revelando aspetos da sua própria vida e personalidade, tais como o seu divórcio, a atração por mulheres jovens, o desacordo com a filha, Andrea, a propósito do namorado... E a sua vida acaba por tomar um novo rumo, tendo relações mais pacíficas com as pessoas que lhe são mais chegadas. No final do romance, os protagonistas reúnem-se no casamento de Andrea e Carlos, o namorado desprezado. Nesse autêntico happy end, o jovem casal, agora com um filho, faz as pazes com o pai de Andrea, e Saldaña Paris, romancista com futuro, apresenta a nova namorada. Finalmente, a "biografia dos amantes" pode também ser a de qualquer personagem do romance que sente afeto e se relaciona com os outros. A biografia pode ter uma dimensão autobiográfica já que o "eu", ao falar de outrem, fala também de si-próprio, através de um processo de identificação. De facto, o leitor tem uma certa forma de liberdade para interpretar e classificar genericamente o romance, uma vez que o pacto de leitura não é totalmente explícito e que o autor não respeita os moldes tradicionais da biografia.

A incerteza genérica também atinge a narrativa em abismo no romance. Com efeito, a questão da autoria do manuscrito de Bríon faz com que surja uma dúvida quanto ao estatuto genérico desse texto. Sendo Teresa a autora, trata-se de uma autobiografia, porém, o narrador desconfia da identidade do verdadeiro autor:

Ocorria-me, em primeiro lugar, que o texto não devia ter sido escrito por Teresa de Sousa, uma vez que estava escrito num galego perfeito. Segundo o que eu sabia, Teresa nascera em Portugal, abandonara os estudos bastante cedo, falava uma mistura de línguas quando Saldaña Paris a conhecera vivera com este em Londres e só regressara à Galiza em data incerta; seria muito difícil ter aprendido o galego normativo. Em segundo lugar, o texto terminava abruptamente, e ficávamos sem saber o que acontecera depois de Teresa ter feito as malas e decidido partir. (TORDO, 2014, p. 191) 
Se o manuscrito é da autoria do amigo de Teresa, Benxamín, o texto será uma autoficção, uma vez que o autor finge assumir a identidade da mulher. No entanto, é de destacar que é o próprio narrador, leitor do manuscrito, que põe em causa a autoria, revolvendo assim as fronteiras genéricas. Sendo assim, ele altera a identidade do "eu", lembrando o papel fundamental do leitor na interpretação do texto.

Ambos os romances propõem uma reflexão sobre a escrita na primeira pessoa, apontando para o caráter problemático e incerto do "eu". Essa questão é sugerida, em Livro, pelas inúmeras referências a obras e autores ligados com a escrita na primeira pessoa e com o paradigma autoficcional, em que Livro também se insere: Dylan Thomas, Sylvia Plath, Marcel Proust, Virginia Woolf, Albert Camus, James Joyce, Marguerite Yourcenar, Albert Cohen, Mark Twain, Mary Shelley e muitos mais. É de salientar também a escolha do nome da namorada de Livro, Sidonie, uma alusão óbvia a Sidonie-Gabrielle Colette, precursora da autoficção. Podemos também observar a referência repetida a Voyage au bout de la nuit, de Louis-Ferdinand Céline, que nos leva a refletir sobre as ligações entre o livro e a vida, sendo o romance um exemplo invulgar de escrita intimista, com teor autobiográfico, que propõe, segundo a expressão de Sébastien Hubier, uma "oscilação contínua entre a realidade e a imaginação" 21 :

A existência e a escrita são os dois aspetos de uma mesma realidade, e é sem dúvida esse sentimento, repetidamente expresso, de ter vivido consoantes as exigências da sua obra, que leva Céline a atravessar o limite que separa habitualmente as diferentes escritas na primeira pessoa, a transformar o romance em autobiografia, antes de transformar esta última numa ficção (HUBIER, 2003, p. 118, tradução nossa).

${ }^{21} \mathrm{Cf}$. HUBIER, Sébastien, Littératures intimes. Les expressions du moi, de l'autobiographie à l'autofiction. Paris : Armand Colin, coll. U-Lettres, 2003, p. 118.
O livro de Céline põe em destaque a interligação profunda entre a vida e a escrita, um vínculo patente no impacto que tem a sua leitura na vida das personagens. Voyage au bout de la nuit coloca a questão da dimensão ética da literatura e da possibilidade de apreciar uma obra de qualidade embora o autor não tenha uma vida exemplar (é, no caso de Céline, o antissemitismo e o papel ativo de colaborador durante a segunda guerra mundial que levantam um problema). 0 romance está associado com a morte de Galopim, o amigo de infância de Ilídio, ou com cenas de sexo com Sidonie (que tem relações com Livro em troca de literatura), sendo as noções de corrupção, vício, sordidez e materialismo inseparáveis do livro. Na noite em que Sidonie devolve Voyage au bout de la nuit ao amante, Livro atropela uma mulher ao tentar abrir o vidro do carro em andamento para se livrar do mau cheiro do romance de Céline. Ora, sendo uma costureira portuguesa com 81 anos de idade, tudo indica que a mulher morta é a própria avó de Livro. Por conseguinte, o livro afeta radicalmente a personagem, aniquilando uma parte da sua família e, por conseguinte, da sua vida e do próprio Livro, levando a personagem a voltar ao princípio, à origem, para resgatar o Livro. De regresso a Portugal com a mãe, esta entrega-lhe o livro - assim como o fez a mãe de Ilídio no início do romance - que poderá assim chegar, indemne, até ao leitor. $\mathrm{O}$ romance oferece sempre a possibilidade de voltar ao princípio e de ressuscitar personagens que, de facto, nunca morrem.

O livro de Céline enfatiza a ideia que "um livro emprestado nunca pode ser devolvido" (PEIXOTO, 2010, p. 252), um leitmotiv que aparece no romance. Com efeito, o livro passa a fazer parte da vida de quem o lê, transformando o leitor. A biblioteca pessoal constitui uma espécie de código genético, uma assemblagem aleatória e muito pessoal de obras que variam em quantidade e qualidade de um indivíduo para o outro. Livro afirma, aliás, evocando a sua biblioteca pessoal: "Os livros que tenho nas estantes formam um desenho de mim: o que quero lembrar e o que não quero esquecer" (PEIXOTO, 
2010, p. 252). Quem lê um livro nunca se consegue desfazer totalmente dele, embora o devolva a quem lho emprestou, e quem empresta também partilha um pouco de si-próprio. A personagem de Constantino emblema essa ideia visto que representa o leitor pervertido pelos livros que leu, e que escolheu ler, livros com uma ideologia implacável, que lhe "fazem mal" (PEIXOTO, 2010, p. 164), alterando a sua identidade. Em consequência, Constantino acaba por identificar-se com Lenine, sendo a seguir internado num hospital psiquiátrico. Na sequência desses acontecimentos, Livro queima alguns livros do padrasto que, segundo ele, "antologiavam a incoerência emocional e intelectual do Constantino em volumes, tomos de veneno e azia. Como uma enciclopédia: Aberração a Desespero; Despotismo a Incapaz; Incómodo a Preconceito; Prepotente a Zangado." (PEIXOTO, 2010, p. 215). Um fenómeno semelhante de identificação observa-se em Biografia involuntária dos amantes com, por exemplo, a personagem de Teresa que se apelida a si-própria de "Teresa de Sousa Inútil" no seu manuscrito (TORDO, 2014, p. 109), em referência a um livro de poemas do ex-marido: "Dei um título estúpido ao livro: chamei-lhe Inútil. Referia-me a mim-próprio, claro está. Nunca foi publicado. No entanto, passado algum tempo recebi uma carta de uma editora acabada de fundar cujo nome era Editions de l'Inutile." (TORDO, 2014, p. 44-45).

Não é apenas o "eu" do narrador que é interrogado no romance contemporâneo, como também a própria identidade do leitor. Por exemplo, na página 207 de Livro, o leitor depara-se com um questionário com doze perguntas precedidas de uma ordem no imperativo: "Indique os seguintes dados". Espontaneamente, sente-se obrigado a responder e só nas páginas seguintes descobre que as perguntas não lhe são dirigidas. Ademais, por intermédio da metalepse, o leitor fica com um exemplar de Livro na sua posse, tendo o objeto, oriundo do mundo das personagens, atravessado a fronteira entre o real e a ficção. Essa transgressão leva o leitor a refletir sobre a sua própria identidade, embora confirme também a existência de um limite entre a ficção e o real, assim como explica Françoise Lavocat:

A fusão dos mundos não se dá, uma vez que o princípio de qualquer obra metaléptica é jogar com a fronteira, revelando-a ao simular atravessála. 0 resultado não é a sua eliminação, tornando-se, pelo contrário, mais manifesta - concebível, visível, imaginariamente tateável: essa experiência do pensamento é o privilégio da ficção e, ao que parece, nunca a valorizámos tanto como temos feito ultimamente (LAVOCAT, 2016, p. 480, tradução nossa).

Ao recorrer a essa técnica, o autor sugere a invasão do mundo do leitor pela ficção, simbolizando o impacto que a leitura, e o próprio Livro, têm na sua vida. Além disso, a transgressão da fronteira entre o real e a ficção traduz uma aproximação do leitor e do autor, reafirmando a existência deste último. O romance constitui assim um espaço de contacto, como se uma fração do "eu" do autor passasse a integrar o "eu" do leitor. No romance contemporâneo, o autor está profundamente investido na obra e na sua relação com o público, contradizendo a abordagem estruturalista do texto:

[...] a onda metaléptica atual representa o desmentido ou a consequência da declaração de óbito, há meio século, dos autores e das personagens. Nas obras muito contemporâneas, é uma demonstração da omnipresença do autor que a metalepse permite implementar [...] (LAVOCAT, 2016, p. 519, tradução nossa).

De forma geral, ambos os romances entretêm a confusão do livro com o indivíduo, o texto funcionando de modo metonímico, como substituto de um ente querido, desaparecido ou afastado. Em Livro, a mãe de Ilídio, ao abandonar o filho, deixa-lhe uma parte de si-própria, fazendo com que a criança não permaneça sozinha na fonte, mas fique com o livro e a mala, símbolos de um futuro ainda por escrever. 0 mesmo livro será, mais tarde, oferecido por Ilídio a Adelaide, a namorada, e esta levá-lo-á consigo ao emigrar 
para França. Durante a viagem, o contacto físico com o livro apazigua-a como se esse conforto lhe fosse outorgado pelo próprio Ilídio:

[...] Adelaide abriu a mala. Afastou as roupas com delicadeza e encontrou o livro. Passou-lhe a ponta dos dedos pela capa, sentiu-o. Depois, levantou-o com as duas mãos, deslizou-o ao longo da pele do rosto, tocou-o com os lábios. Enquanto o abraçou, manteve os olhos fechados (PEIXOTO, 2010, p. 110).

Além disso, cada sinal tipográfico do romance representa o equivalente de uma vida real:

Até este xis, este: $\mathrm{X}$, o livro que estás a ler tem 404853 caracteres, incluindo notas de rodapé e espaços.

Em 1990, viviam na França um total de 798837 pessoas de origem portuguesa, 603686 dos quais nascidos em Portugal e 195151 nascidos na França.

Cada letra e cada espaço das páginas anteriores equivale a quase duas pessoas de origem portuguesa a viverem na França em 1990 (PEIXOTO, 2010, p. 260)

Da mesma forma, em Biografia involuntária dos amantes, o manuscrito de Bríon é um substituto de Teresa que veicula as suas falhas e mistérios.

Dentro do romance, a vida e os textos confundem-se, indicando uma influência mútua, quase uma identidade, e esse entrançamento desempenha um valor simbólico, representando as transformações do indivíduo devidas ao seu relacionamento com o Outro, inclusive através de um texto. Além disso, Livro e Biografia involuntária dos amantes revelam a porosidade de um "eu" não hermético ao mundo da ficção, que vai integrando leituras. Por seu lado, o autor, transfigurado pela ficção, evoca com autenticidade uma sociedade e um mundo com que se relaciona intimamente sem, porém, assumir qualquer compromisso com a verdade. As consequências de todas estas tendências são, nas novas escritas íntimas, um certo abalo das fronteiras entre géneros próximos, tais como a biografia, a autobiografia e a autoficção.

\section{Conclusão}

Ao observamos o delineamento das fronteiras do romance em dois exemplos de obras recentemente publicadas, representativas, a nosso ver, das mais recentes tendências da escrita romanesca, parece-nos óbvia a expansão dos limites do romance para territórios cada vez mais alargados, inclusive o próprio leitor.

Essa dilatação traduz-se numa dimensão intertextual assumida que revela uma assimilação de obras alheias - consagradas ou não, de quaisquer épocas ou nacionalidades - e uma inscrição numa rede de textos, com os quais o autor tem mais ou menos afinidades, que vão moldando a escrita. Torna-se óbvio também o diálogo com a tradição, história e teoria literárias, com elementos que podem ou não ser aproveitados pelo autor, consoantes as suas necessidades e vontade, preservando assim a liberdade de se inserir, ou não, numa escola ou movimento. Além disso, ambos os romances apontam para a possibilidade de serem prolongados, nomeadamente através da "transficcionalidade", inclusive pelo próprio leitor que desempenha um papel cada vez mais ativo no romance. A expansão é também espacial já que as obras apresentam uma dimensão internacional que se revela através do percurso de personagens que superam fronteiras ao deslocarem-se e viajarem. Ademais, tanto Livro como Biografia involuntária dos amantes inserem livros nos contextos mais prosaicos e na vida de personagens que poderíamos julgar pouco afeitas à leitura e à escrita. Traduz-se assim uma tendência da literatura para investir o dia-a-dia de um público cada vez mais variado (amador de blogs literários, redes sociais, sites oficiais de autores, feiras e salões do livro...), ocupando um espaço social alargado. Por fim, o romance 
também se expande transgredindo as fronteiras entre o real e a ficção, a vida e o livro, recorrendo com frequência à metalepse. A nosso ver, esses elementos simbolizam o caráter mais abrangente e "descompartimentado" do romance que se exporta, investe todas as esferas da sociedade, está presente no quotidiano do leitor, com autores que intervêm em todos os aspetos da produção literária e que se tornam cada vez mais acessíveis para o público.

As tendências aqui apontadas pedem, como é óbvio, para ser confirmadas através do estudo de um corpus mais alargado e da observação de obras ainda por publicar. Contudo, parece-nos que a dimensão individual acima apontada é uma tendência relevante do romance contemporâneo. 0 desenvolvimento da literatura com caráter íntimo, em que a sociedade, a História, os problemas alheios, são encarados sob um ponto de vista individual, revela a importância da individualidade na época atual. Ao refletir sobre a escrita íntima e o desenvolvimento atual da "autonarração" (um neologismo alternativo para designar a autoficção), Philippe Gasparini salienta que, na perspetiva do contexto da "globalização e mundialização",

A autonarração do século XXI inscreve-se, no meu parecer, nesse anseio por uma voz singular, livre, desconetada dos circuitos económico-políticos, autónoma. À moldagem dos comportamentos que exige o mercado, ela opõe uma busca individual, obstinada, sinuosa, incerta, interminável. Na cacofonia do falso debate público, abre espaços interiores de retrospeção, de reflexão, de comunicação; e até de silêncio (GASPARINI, 2008, p. 327 tradução nossa).

De forma paradoxal, a intimidade está, hoje em dia, ameaçada, tendo sido demasiado exposta nos médias, desenvolvendo assim aspetos inautênticos, fingidos, artificiais. São, por conseguinte, as consequências de um certo "individualismo paradoxal", referido no início deste estudo, que transparecem na escrita contemporânea. Mostrar uma implicação e um relacionamento íntimo com o Outro, a História, a sociedade, os livros... é um desafio do romance atual que vai preservando, assim, um território individual ameaçado por uma certa versatilidade e corrupção.

\section{Referências}

ALMEIDA REGO, Vânia. La mise en scène du "je" dans l'œuvre de José Luís Peixoto problématiques de l'écriture de soi. Tese, dirigida por Anne-Yvonne Julien, Sandra Teixeira e Sérgio Sousa, (Doutorado) - Universidade de Poitiers, França, 2015.

AUGÉ, Marc. Non-lieux. Introduction à une anthropologie de la surmodernité. Paris: Seuil, coll. La librairie du XXIème siècle, 1992.

CHEVALIER, Jean; GHEERBRANT, Alain, Dictionnaire des symboles. Mythes, rêves, coutumes, gestes, formes, figures, couleurs, nombres. 2. éd. revue et corrigée. Paris: Robert Laffont/Jupiter, 1982 (1 1 ère éd. 1969). (Coll. Bouquins).

COLONNA, Vincent. Autofiction et autres mythomanies littéraires. Auch: Tristram, 2004.

DÄLLENBACH, Lucien. Le récit spéculaire. Essai sur la mise en abyme. Paris: Seuil, 1977. (Coll. Poétique)

GASPARINI, Philippe. Autofiction. Une aventure du langage. Paris: Seuil, 2008. (Coll. Poétique).

GENETTE, Gérard. Palimpsestes. La littérature au second degré. Paris: Seuil, 1982

HUBIER, Sébastien. Littératures intimes. Les expressions du moi, de l'autobiographie à l'autofiction. Paris: Armand Colin, 2003. (Coll. U-Lettres).

LAVOCAT, Françoise. Fait et fiction. Pour une frontière. Paris: Seuil, 2016. (Coll. Poétique). LIPOVETSKY, Gilles; CHARLES, Sébastien, Les Temps hypermodernes. Paris: Grasset, 2004. (Coll. Biblio essais).

LIPOVETSKY, Gilles. L'Ère du vide. Essais sur l'individualisme contemporain. Paris: Gallimard, 1983.

MONTALBETTI, Christine, Le voyage, le monde et la bibliothèque. Paris: Presses Universitaires de France, 1997.

PEIXOTO, José Luís. Livro. Lisboa: Quetzal, 2010.

Cemitério de pianos. Lisboa: Quetzal, 2006 
Morreste-me. Lisboa: Quetzal, 2000.

REAL, Miguel. Crítica a Livro. Jornal de letras, artes e ideias, n. 1042, p. 10-11, 8 a 21 de dez. 2010.

RYAN, Marie-Laure, Frontière de la fiction: digitale ou analogique? In: GEFEN, Alexandre; AUDET, René (Dir.). Frontières de la fiction. Québec: Éditions Nota bene, 2001.

SAINT-GELAIS, Richard, La fiction à travers l'intertexte: pour une théorie de la transfictionnalité. In: GEFEN, Alexandre; AUDET, René (Dir.). Frontières de la fiction. Québec: Éditions Nota bene, 2001.

SCHAEFFER, Jean-Marie, Métalepses. Entorses au pacte de la représentation. Paris: École des Hautes Études en Sciences Sociales, 2005.

SCHAEFFER, Jean-Marie. Pourquoi la fiction? Paris: Seuil, 1999.

TORDO, João. O Paraíso segundo Lars D. São Paulo: Companhia das Letras, 2015.

. O Luto de Elias Gro. São Paulo: Companhia das Letras, 2015.

Biografia involuntária dos amantes. Alfaguara, Portugal: Editora Objetiva, 2014.

O bom inverno. Lisboa: D. Quixote, 2010.

Hotel memória. Porto: Quidnovi, 2007.

VAZ MARQUES, Carlos, "O Livro sou eu. Sou eu mascarado" (Entrevista com José Luís Peixoto). Ler. n. 95, p. 30-36, out. 2010.

Recebido em 23/09/2016.

Aceito em 23/11/2016. 